\title{
Website Usability in Marketing Communications: The Case of Airline Companies in Turkey
}

\author{
Eylin BABACAN AKTAŞ ${ }^{1}$, Özge MUTLU ${ }^{2, *}$ \\ ${ }^{1}$ Department of Public Relations and Publicity, Pamukkale University, Denizli, Turkey \\ ${ }^{2}$ Department of Public Relations and Advertising, Institute of Social Sciences, Eskişehir, Turkey \\ *Corresponding author: ebabacan@pau.edu.tr
}

\begin{abstract}
It is of great importance for the organizations to use internet environment effectively in a market where competition conditions are gradually aggravated and carry out their marketing communication activities in such an environment. Airline companies are the ones that use internet technology most effectively and actively. Thus, website usability is of great importance for airline companies. The aim of this study is to make an analysis concerning website usability as a means of marketing communication. In line with this objective, web site of the airline companies operating in Turkey have been analyzed and the roles assumed by the analyzed websites as a marketing communications tool have been tried to set forth. The methodology of the research is based on scoring system of Gibson et al. [9]. Under the study, web sites of the airline companies in Turkey was monitored for a month between 2012 and 2014 and they were assessed in various dimensions such as functions (information provision, networking, participation, campaigning, online processes, mobile applications, social media applications) and delivery (glitz factor, access, navigability, freshness, visibility). The findings revealed that websites made progress over the years; however, online, mobile and social media applications remained incapable in terms of marketing communications targets.
\end{abstract}

Keywords: marketing communications, website usability, airline industry, Turkey

Cite This Article: Eylin BABACAN AKTAŞ, and Özge MUTLU, "Website Usability in Marketing Communications: The Case of Airline Companies in Turkey.” American Journal of Educational Research, vol. 3, no. 10A (2015): 7-16. doi: 10.12691/education-3-10A-2.

\section{Introduction}

Technology and especially internet technology has had an impact on almost every area. Internet has found itself as an indispensable media in various areas such as education, health, science, and telecommunication.

As for many areas, Internet is also an indispensable media for competitive institutions and brands. Organizations and brands that aim to remain ahead of their rivals and protect and maintain their existence in the market with marketing communication applications see internet environment as an opportunity to create such differentiation. Therefore, internet has become much important in terms of marketing communication applications as well as all other areas. One of the most important points making the internet a powerful marketing communication media is that it is a communication media that puts target audience and organization together where organizations could reach their target audience effectively. In a market where conditions of competition are gradually aggravated, effective use of internet media by the organizations and maintaining their marketing communications activities in such media are regarded as the most important application.

Evaluation of web sites and internet media that we encounter as various types like social media is very important in terms of providing differentiation and competitive advantage. It is possible to investigate internet environments from various aspects such as usability, visibility, content, quality. Especially, website usability may be seen as a significant variable with respect to introducing the effectiveness of the website that is designed as a point of meeting with the target audience.

Today, nearly all organizations have web sites. However, it is expected that these web be suitable for marketing communications, effectively meet the target audience and create a positive image for the organization and/or the brand. Such expectations reveal qualitative and quantitative analysis and evaluation styles regarding websites and efforts to measure website efficiency. Website usability should be seen a major study area with regard to measurement of websites efficiency within communication marketing applications.

The objective of this study is to make an analysis on website usability as a marketing communication tool. In line with this aim, web sites of the airline companies operating in Turkey have been analyzed and the roles assumed by the analyzed websites as a marketing tool have been tried to set forth.

\section{Literature Review}

The number of internet users has been increasing in Turkey and in the World. In 2014, the number of 
worldwide internet users was over 3 billion [28]. In Turkey, 46 million people use internet, which accounts for $57 \%$ of the population [28]. Taken intensive use of internet into consideration, the importance of internet in terms of marketing communication and being a meeting point for the target audience have come in view.

\subsection{Marketing Communications and Websites}

On one hand, development of internet technology is a factor increasing pace of competition environment; it is the most significant tools to increase efficiency of communication activity that we regard as one of the most powerful ways to take the advantage of competition through differentiation.

Efficiency in marketing communication strategies can be provided with the strategies appropriate for the characteristics of the target audience taking the competition environment into consideration and designed as a way of differentiation from the rivals. The media used to communicate with the target audience have distinct advantages and disadvantages. However, a two-way communication is an important factor that may increase the impact on the target audience. A two-way communication will provide opportunity to identify the target audience. This identification will both give the chance to produce message for the target audience and enable the organization to have the ability to response the needs and demands similar to that of achieved through face-to-face communication. The most crucial benefit the internet provides to the private enterprises and public institution is the structure allowing bidirectional $([13,16])$, interactive and symmetric communication [13]. On the other hand, internet may become an interactive media that can be used for 24 hours uninterruptedly, and enable oneto-one relations with its integrative features [21]. Such facilities of the internet enables internet come to the forefront as a unique tool for the implementation of marketing communication strategies. [4].

As internet has certain features of mass communication and personal communication, it has come into existence as a hybrid communication channel and therefore it has advantages of both mass communication and personal communication.

Interactive nature of internet and the web distinguish them from traditional media. While the web can be used to disseminate messages like traditional media, it is also used to collect data about the target audience and to monitor the public concerning the issues of the organizations [6]. On the other hand, multi-dimensional structure of the internet and its speed to convey the messages [12] result in various facilities in terms of marketing communication strategies.

\subsection{Travel, Airlines and Websites}

Following analysis of the importance of internet and web in terms of marketing communication, the literature concerning internet and websites in travel and airlines industry that fall within the scope of the study should be reviewed. As known, airlines are the organizations within travel industry. Accordingly, studies on travel industry and internet should be assessed within the frame of a study on airlines.

One of the intended use of internet as well as many others is the travel. Tourists use internet intensively for many purposes from obtaining information and buying products to making comparisons. When the literature about the use of internet in travel industry is reviewed, Connolly, Olsen and Moore [3] studied the internet in travel industry as a channel of distribution and stated that internet comes to the forefront as a tool providing information for potential customers and enabling price comparison. Similarly, Brunger and Perelli [1] investigated the internet as a channel of distribution and focused on the behaviors of internet users about buying travel products. Lang [17] reported that with the internet, distribution channels and ways of doing business changed, while buying behaviors started to differentiate as the consumers became more experienced about the technology. Heung [11] emphasized the place of internet in travel industry as a source of information and a platform where a product is purchased, whereas Küster [15] discussed the internet as a relational tool in airline and rent a car services in terms of travel companies. Law and Wong [18] put emphasis on success factor of travel web sites concerning purchase and drew attention to security and design elements while Perdue [20] discussed basic factors in evaluation of websites.

It can be said that airline companies are the pioneers [2] in utilization of information and communication technologies as part of travel industry. Buhalis [2] reported that airline companies use internet to develop their distribution strategies and reduce the costs thereof. There are many studies showing airline companies use internet as a tool for distribution of airline tickets (For example [14,22,27]). Particularly, distribution of airline tickets via websites has made airline web sites an important media.

Analyzing the performance of airline websites, Harison and Boonstra [10] suggested a performance assessment within the frame of eight dimensions including finance, customer satisfaction, traceability, accessibility, contact, sales, after-sales and customer support. Tsai, Chou and Leu [25] suggested a model aiming website effectiveness as a web based marketing tool in airline industry.

When the literature is reviewed, studies on the quality of airline web sites are remarkable. Sam and Tahir [23] discussed website quality within the frame of usability, website design, information quality, trust, perceived risk and empathy dimensions, analyzed the impact of website quality on consumer online purchase intention of air ticket and found that empathy and trust are the factors that affect online purchase behavior. Similarly, having studied on website quality in airline industry, Shchiglik and Barnes [24] suggested four dimensions such as site quality, information quality, interaction quality and airline-specific quality in website quality assessment. Another study on website quality was conducted by Xie and Barnes [26]. Xie and Barnes [26] defined quality assessment dimensions concerning website quality of UK airlines as usability, web site design, service quality, information quality and enjoyment.

As well as studies on quality of airline websites, in literature there are outstanding studies on website satisfaction and loyalty. Lubbe [19] reported in his study on satisfaction on airline websites, certain demographic features and level of use of airline websites could affect such satisfaction. Forgas et al. [7] investigated loyalty towards airline websites and pointed out that conative e- 
loyalty towards the website arises through stages not directly. For this, affective e-loyalty, e-trust, e-satisfaction and a positive offline perceived value should be provided in the first place. Studying on moderating effects of gender and education on loyalty towards an airline website, Forgas-Coll et al. [8] stated that website quality, esatisfaction, e-trust and affective e-loyalty were the antecedent of conative e-loyalty and emphasized that university level education affected the loyalty positively. Elkhani, Soltani and Jamshidi [5] studied airline websites from the perspective of customers and put an emphasis on the importance of gaining new customers and making existing customers loyal. It is found that customer disconfirmation which was evaluated as a variable in the study has a positive impact on e-satisfaction and accordingly e-satisfaction impacts e-loyalty in a positive way [5].

As can be seen, there are various studies on internet use in airline industry, especially on websites that is a part of both travel and travel industry. Particularly, web-based marketing, website quality, e-satisfaction, e-loyalty and effectiveness assessment are prominent. This may result from the fact that websites of the airlines are used more intensively and actively than the other companies. On the other hand, active use of airline websites and the requirement of structuring satisfactory and quality websites for the users may be of importance with regard to evaluation of websites as a marketing communication tool.

\section{Methodology}

Websites are the media that can be evaluated both qualitatively and quantitatively. In this study, a quantitative approach is employed and a content analysis is made towards website usability. The methodology of the research is based on scoring system of Gibson et al. [9]. The strong side of the scoring system used by Gibson et al. [9] is the flexibility it provides for reshaping depending on different disciplines, subject or industries.

According to the scoring system there are two main parts of website analyzing: Functions (information provision, networking, participation, campaigning and resource generation) and delivery (multimedia/glitz factor, access, navigability, freshness, visibility). Based on two main dimensions, an adaptation to the requirements of airline industry and today's technology has been made in the study. For example, although it is not found in the original index, sub dimensions such as online processes, mobile applications and social media applications are included in the adopted index. On the other hand all subdimensions are rearranged according to the airline industry. It is possible to find original and modified version of the scoring system in Appendix 1 and 2 relatively.

Within the frame of the content analysis scoring system for website usability adopted from Gibson et al. [9], websites of airline companies operating in Turkey were studied 1-30 September 2012 and 1-30 April 2014 respectively. By this means, it was possible to make a comparison between the airline companies and monitor both the development of website usability between 2012 and 2014. The airline companies and web sites analyzed are as the following:
- Anadolu Jet - www.anadolujet.com/aj-tr/

- Atlas Jet - www.atlasjet.com/

- Bora Jet - www.borajet.com.tr/

- Onur Air - www.onurair.com.tr/

- Sun Express - www.sunexpress.com/

- Pegasus Airlines - www.flypgs.com/default.aspx

- Turkish Airlines - www.turkishairlines.com/tr-tr/.

\section{Findings}

The study analyzed web sites of Anadolu Jet, Atlas Jet, Bora Jet, Onur Air, Pegasus Airlines, SunExpress and Turkish Airlines (THY). In accordance with the analysis, the effectiveness of website usability in terms of providing contribution to marketing communication studies based on functions and delivery features of the websites of the airline companies operating in Turkey. The findings on functions and delivery dimensions of the websites are as the following.

\subsection{Functions}

In order to reveal the features of function, an analysis within the dimensions of information provision, networking, participation, campaigning, online processes, mobile applications and social media applications. The findings on functions of the websites analyzed are summarized in Table 1 (For detailed scoring table, see Appendix 2).

When the websites of airlines companies operating in Turkey are reviewed, it is seen that there is a top to bottom communication process and information provision. As a result of analysis with regard to information provision, it is found that websites of Turkish Airlines and Pegasus Airlines provide richer information provision than the others. The websites of Atlas Jet and Onur Air come after the others. It is observed that all companies share "history, FAQ, fleet, customer relations" information. The airline company where the less information flow is provided is Bora Jet. The website of Bora Jet should be improved in terms of information provision and communication network. It is also found that Onur Air web site does not have "privacy policy" option, Bora Jet web site does not have "security policy" option and the websites of Atlas Jet and Bora Jet do not have Lost Property option. It is clear that no significant improvement with regard to information provision between 2012 and 2014 except for Atlas Jet.

When web sites are analyzed in terms of Networking, the websites of THY, Anadolu Jet and Atlas Jet, "agencies and head office contact information and reference links" are used intensively while in other airlines, such share is limited. It is found that e-mails of managers are not shared in any of the airline companies. The web site of Bora Jet has showed significant improvement on networking between 2012 and 2014.

When it comes to Participation facilities, it is observed that only Pegasus Airlines offer "membership" facility and create a "forum" for the visitors while Atlas Jet has an option of "opinions and suggestions" in addition to membership. However, THY, Onur Air and SunExpress only have membership options on their websites. When the findings between 2012 and 2014 are compared, it is 
seen that only the websites of Atlas Jet and Pegasus Airlines have improved.

Table 1. Functional Characteristics of Websites

\begin{tabular}{|c|c|c|c|c|c|c|c|c|}
\hline & & $\begin{array}{c}\text { Information } \\
\text { Provision }\end{array}$ & Networking & Participation & Campaigning & $\begin{array}{c}\text { Online } \\
\text { Processes }\end{array}$ & $\begin{array}{c}\text { Mobile } \\
\text { Applications }\end{array}$ & $\begin{array}{l}\text { Social Media } \\
\text { Applications }\end{array}$ \\
\hline \multirow{2}{*}{ ANADOLU } & 2012 & 12 & 11 & 0 & 3 & 5 & 0 & 0 \\
\hline & 2014 & 12 & 11 & 0 & 3 & 5 & 2 & 0 \\
\hline \multirow{2}{*}{ ATLAS } & 2012 & 13 & 12 & 1 & 0 & 3 & 5 & 3 \\
\hline & 2014 & 16 & 12 & 2 & 0 & 3 & 3 & 3 \\
\hline \multirow{2}{*}{ BORA } & 2012 & 7 & 2 & 0 & 0 & 3 & 0 & 2 \\
\hline & 2014 & 9 & 7 & 0 & 0 & 3 & 0 & 3 \\
\hline \multirow{2}{*}{ ONUR } & 2012 & 15 & 8 & 1 & 2 & 3 & 0 & 3 \\
\hline & 2014 & 16 & 8 & 1 & 2 & 3 & 3 & 3 \\
\hline \multirow{2}{*}{ PEGASUS } & 2012 & 20 & 9 & 1 & 3 & 4 & 0 & 5 \\
\hline & 2014 & 20 & 9 & 2 & 3 & 5 & 3 & 4 \\
\hline \multirow{2}{*}{ SUNEXPRESS } & 2012 & 16 & 7 & 1 & 1 & 3 & 0 & 0 \\
\hline & 2014 & 15 & 7 & 1 & 1 & 3 & 0 & 4 \\
\hline \multirow{2}{*}{ THY } & 2012 & 21 & 15 & 1 & 3 & 5 & 5 & 6 \\
\hline & 2014 & 21 & 15 & 1 & 3 & 5 & 6 & 6 \\
\hline INTERVAL & & $0-21$ & $0-20$ & $0-4$ & $0-3$ & $0-5$ & $0-7$ & $0-6$ \\
\hline
\end{tabular}

Note: Anadolu Jet (ANADOLU), Atlas Jet (ATLAS), Bora Jet (BORA), Onur Air (ONUR), Pegasus Airlines (PEGASUS) and Turkish Airlines (THY).

When web sites are analyzed in terms of Campaigning, it is seen that the websites of THY and Pegasus Airlines have the features of "attending online campaign", "download logo, brochure and campaign information". Following these websites, comes the website of Onur Air. There was not change in the websites between 2012 and 2014.

As for Online processes, it is observed that THY, Anadolu Jet and Pegasus Airlines provided services of "online reservation, online ticket sale, online check-in, online luggage check and online cargo tracking”. However, Atlas Jet, Bora Jet, Onur Air and SunExpress only provided services of "online reservation, online ticket sale and online check-in”. There was an improvement in Pegasus Airlines between 2012 and 2014.

It is seen obviously that Turkish Airlines is well ahead of other airline companies concerning mobile applications. While Atlas Jet, Onur Air and Pegasus Airlines followed THY in terms of mobile applications, other airline companies fell behind. There were significant changes in the websites between 2012 and 2014. During analysis, no mobile applications were found in the websites of Anadolu Jet, Onur Air and Pegasus Airlines while, in 2014, mobile applications were included in the web sites.

When social media applications are analyzed, it is revealed that THY uses all applications of "RSS, Facebook, Twitter, Google+, Youtube, Flickr”. It is found that Pegasus Airlines is ranked the second in social media applications while other airline companies have insufficient web sites concerning social media applications. SunExpress did not include any social media applications in 2012, whereas it started to use four social media application in 2014.

\subsection{Delivery}

In order to find out delivery features of the study, an analysis was made within the frame of glitz factor, access, navigability, freshness, and visibility dimensions. The findings concerning delivery dimension of the web sites analyzed are summarized in Table 2. (For detailed scoring table, see Appendix 2).

When design index is analyzed, it is observed that most of the airline websites carry the required qualities while SunExpress seems to be more insufficient in terms of "moving/images" than the others. Compared in terms of multimedia index, we observed that the websites of THY, Anadolu Jet and Onur Air have multimedia index whereas the websites of Pegasus Airlines and SunExpress should be improved in this regard. There were not any significant changes in the websites with regard to design index and multimedia index between 2012 and 2014.

When we analyzed the web sites from the point of access, it is found that the websites of Onur Air and Pegasus Airlines have the accessibility at the best level which is followed by the websites of THY, Atlas Jet and Bora Jet while the websites of Anadolu Jet and SunExpress have the least accessibility level. However, no airline companies have the application of "blind/visually impaired software” item under accessibility option. There was a change in the website of Pegasus Airlines with regard to Access between 2012 and 2014.

When the websites are analyzed in terms of navigability, it is observed that the websites of Anadolu Jet and Bora Jet are at the best level, which is followed by the website of the Turkish Airlines while the websites of the other airline companies should be improved with regard to navigability. When a comparison is made between 2012 and 2014, it is seen that the website of Bora Jet is improved whereas there is a decline in the websites of SunExpress and Turkish Airlines.

When the websites are analyzed with regard to Freshness, it is seen that most updating is done on the website of Pegasus Airlines. Anadolu Airlines is ranked as the second, which is followed by the websites of THY and SunExpress. There was improvement in all websites except for Atlas Jet and Onur Air Freshness between2012 and 2014. 
Within the scope of visibility index, an analysis was made with the Google, the search engine preferred most by the internet users in the World and in Turkey and it is found that THY is the most searched airlines with
26.400.000, while Pegasus Airlines is the second with 21.800.000. When the findings in 2012 and 2014 are compared, it is seen that visibility index of all websites is improved.

Table 2. Delivery Characteristics of Websites

\begin{tabular}{|c|c|c|c|c|c|c|c|}
\hline & & \multicolumn{2}{|c|}{ Glitz Factor } & \multirow{2}{*}{ Access } & \multirow{2}{*}{ Navigability } & \multirow{2}{*}{ Freshness } & \multirow{2}{*}{ Visibility } \\
\hline & & Design Index & Multimedia Index & & & & \\
\hline \multirow{2}{*}{ ANADOLU } & 2012 & 3 & 3 & 2 & 3 & 1 & 31.100 \\
\hline & 2014 & 3 & 3 & 2 & 3 & 6 & 1.440 .000 \\
\hline \multirow{2}{*}{ ATLAS } & 2012 & 3 & 1 & 3 & 1 & 2 & 46.400 \\
\hline & 2014 & 3 & 1 & 3 & 1 & 2 & 797.000 \\
\hline \multirow{2}{*}{ BORA } & 2012 & 3 & 1 & 3 & 1 & 2 & 16.800 \\
\hline & 2014 & 3 & 1 & 3 & 3 & 4 & 450.000 \\
\hline \multirow{2}{*}{ ONUR } & 2012 & 3 & 2 & 4 & 1 & 2 & 91.100 \\
\hline & 2014 & 3 & 3 & 4 & 1 & 0 & 201.000 \\
\hline \multirow{2}{*}{ PEGASUS } & 2012 & 3 & 0 & 3 & 1 & 4 & 206.000 \\
\hline & 2014 & 3 & 0 & 4 & 1 & 6 & 21.800 .000 \\
\hline \multirow{2}{*}{ SUNEXPRESS } & 2012 & 2 & 0 & 2 & 2 & 3 & 418.000 \\
\hline & 2014 & 2 & 0 & 2 & 1 & 5 & 839.000 \\
\hline \multirow{2}{*}{ THY } & 2012 & 3 & 3 & 3 & 3 & 4 & 698.000 \\
\hline & 2014 & 3 & 3 & 3 & 2 & 5 & 26.400 .000 \\
\hline INTERVAL & & $0-3$ & $0-3$ & $0-7$ & $0-4$ & $0-7$ & Link numbers (Google) \\
\hline
\end{tabular}

Note: Anadolu Jet (ANADOLU), Atlas Jet (ATLAS), Bora Jet (BORA), Onur Air (ONUR), Pegasus Airlines (PEGASUS) and Turkish Airlines (THY).

\section{Discussion and Conclusions}

One of the most indispensable remarks of today is transformation. With the development of technology, it is not possible for all of us to keep away from the change. More particularly, production, storage, disseminating information and effective use of it have become easy and pace of information provision has been accelerated thanks to information technologies. We live in a period when the flow of information is passed onto mobile phones from computers, we cannot keep pace with it and when it is difficult to attract attention of the consumers to display buying behaviors and to ensure its continuity. Therefore, information and communication Technologies and internet appear as the most significant factors defining the fate of the organizations and enabling them to differentiate.

With increasing rate of use, while internet has an impact on the fate of organizations, it also provides facilities for the consumers. Especially it has become one of the most important tools for the airline companies where severe competition exists to reach the consumers in airlines companies. Now that it is easily accessed through mobile phones, internet may also affect buying behaviors of the consumers. It has become the most important element for the consumers who can realize buying behavior in any time and conditions. Hence, it would be appropriate to say that marketing communication activities may have impact on decision making process of the consumers. When all such considered, websites, primarily the web sites of airline companies have positioned as most effective tools to describe themselves to their customers. Usability, access, visibility, delivery and functional characteristics provided to the users over the web by an airline company influence the success of the marketing communication strategies. In this regard, it can be said that airline companies have important clues to describe themselves clearly to the consumers through comparative analysis of the web sites. The websites of the airline companies operating in Turkey were analyzed and it is observed that the websites may become more interactive for the consumers in defined areas. Accordingly, there are suggestions concerning websites of airline companies.

When airlines are evaluated with regard to features of their functions, it is possible to say that Turkish Airlines is more efficient in terms of website usability except for participation. Turkish Airlines is followed by the websites of Pegasus Airlines and Atlas Jet. As for participation, it is clear that all websites are insufficient. Primarily, the websites of Anadolu Jet and Bora Jet should be developed in this respect. Also, deficiencies in the websites of Atlas Jet and Bora Jet concerning campaigning should be remedied. It can also be stated that the websites Atlas Jet, Bora Jet, Onur Air and SunExpress should be improved concerning online processes. Although there seems to be improvement regarding mobile applications and social media applications that may be important today when compared to the findings between 2012 and 2014, it is revealed that all airlines apart from THY should make progress. Also, the websites of Bora Jet and SunExpress that do not have any mobile applications should be improved.

When the websites are evaluated in terms of delivery, it is found that the design index of the websites of SunExpress should be developed. As for multimedia index, it is seen that the websites of Pegasus Airlines and SunExpress do not have any content. Development of these websites with regard to multimedia index will provide more effective results for website usability. When we analyzed the websites in terms of Access, it is revealed that the websites of Anadolu Jet and SunExpress are weaker, while all other websites require improvement. It is remarkable that no website has the content concerning 
"Blind/Visually impaired software". As to navigability option, it is observed that the websites of Atlas Jet, Onur Air, Pegasus Airlines and SunExpress should be improved. During the study period in 2014, the website of Onur Air was never updated and Atlas Jet was the other airline having the same updating problem. Since updating is a very important factor for effectiveness of the websites, these websites should be improved concerning updating. Lastly, the website of Onur Air should make a progress with regard to visibility.

Although there were certain changes in the aspect of both dimensions between 2012 and 2014, such changes have not transformed the website usability to a great extent. The most obvious changes from 2012 to 2014 were realized in mobile applications and social media applications. Increasing importance of mobile marketing and more active use of social media today may be stated as the reasons of this change.

Website usability is of great importance for the successful marketing communication strategies. Thus, if the improvements defined above are realized in the websites will allow the use of websites effectively as a meeting point with the target audience and a marketing communication tool.

\subsection{Limitations and Suggestions for Future Research}

In the study, index created by Gibson et al. [9] which was adopted for airline companies was used. Apart from this index, other tools used in website analysis were taken into consideration. Further studies may be conducted through other website content analysis methods.

In this study, web sites were evaluated with regard to semiology. Analysis of websites subject to semiology may beneficial to analyze the websites, to increase effectiveness of websites and satisfaction of the consumers with the websites. Accordingly, it would be useful to analyzed web sites with regard to semiology in future studies.

Only websites of airline companies located in Turkey were analyzed in this study. However, a comparative analysis on important airlines of the World would be of benefit for the development of airlines in our country.

The websites of airline companies operating in Turkey were analyses in terms of website usability in the study. Yet, the expectations of target audience of the airlines companies concerning marketing communications and results of website analysis were not compared herein. It will be very helpful to conduct a survey research to compare expectations of the target audience and findings on website usability to increase the effectiveness of websites and attainment of marketing communication objectives.

\section{References}

[1] Brunger, W.G. and Pereli, S., "The Impact of the internet on airline fares: Customer perspectives on the transition to internet distribution”, Journal of Revenue and Pricing Management, 8 (2/3), 187-199, 2002.

[2] Buhalis, D., "eAirlines: Strategic and tactical use of ICTs in the airline industry”, Information \& Management, 41 (7), 805-825, 2004.

[3] Connolly, D.J., Olsen, M.D. and Moore, R.G, "The internet as a distribution channel”, Cornell Hotel and Restaurant Administration Quarterly, 39 (4), 42-54, 1998.
[4] Doren, D.C.V., Fechner, D.L. and Green-Adelsberger, K., "Promotional strategies on the world wide web", Journal of Marketing Communications, 6 (1), 21-53, 2000.

[5] Elkhani, N., Soltani, S. and Jamshidi, M.H.M., "Examining a hybrid model for e-satisfaction and e-loyalty to e-ticketing on airline websites”, Journal of Air Transport Management, 37 (1), 36-44, 2014.

[6] Esrock, S.L. and Leichty, G.B., "Organization of corporate web pages: Publics and functions”, Public Relations Review, 26 (3), 327-344, 2000.

[7] Forgas, S., Palau, R., Sánchez, J. and Huertas-García, R., “Online drivers and offline influences related to loyalty to airline websites", Journal of Air Transport Management, 18 (1), 43-46, 2012.

[8] Forgas-Coll, S., Palau-Saumell, R., Sanchez-Garcia, J. and Fandos-Roig, J.C., "Airline website loyalty formation and the moderating effects of gender and education”, Service Business, 7 (2), 255-274, 2013.

[9] Gibson, R., Margolis M., Resnick D. and Ward, S., "Election campaigning on the www in the US and UK: A comparative analysis”, Party Politics, 9 (1), 47-75, 2001.

[10] Harison, E. and Boonstra, A., "Reaching new altitudes in ecommerce: Assessing the performance of airline websites", Journal of Air Transport Management, 14 (2), 92-98, 2008.

[11] Heung, V.C.S., "Internet usage by international travellers: Reasons and barriers”, International Journal of Contemporary Hospitality Management, 15 (7), 370-378, 2003.

[12] Ihator, A.S., "Communication style in the information age", Corporate Communications: An International Journal, 6 (4), 199204, 2001.

[13] Jo, S. and Jung, J., “A cross cultural study of the world wide web and public relations”, Corporate Communications: An International Journal, 10 (1), 24-40, 2005.

[14] Koo, B., Mantin, B. and O’Connor, P., “Online distribution of airline tickets: Should airlines adopt a single or a multi-channel approach?”, Tourism Management, 32 (1), 69-74, 2011.

[15] Küster, I., "Relational content of travel and tourism websites", Asia Pacific Journal of Tourism Research, 11 (2), 119-133, 2006.

[16] Lagrosen, S., "Effects of the internet on the marketing communication of service companies", Journal of Services Marketing, 19 (2), 63-69, 2005.

[17] Lang, T.C., "The effect of the internet on travel consumer purchasing behaviour and implications for travel agencies”, Journal of Vacation Marketing, 6 (4), 368-385, 2000.

[18] Law, R. and Wong, J., "Successful factors for a travel web site: Perceptions of on-line purchasers in Hong Kong”, Journal of Hospitality \& Tourism Research, 27 (1), 118-124, 2003.

[19] Lubbe, B., "The effect of internet apprehension and website satisfaction on air travelers' adoption of an airline's website", Journal of Air Transport Management, 13 (2), 75-80, 2007.

[20] Perdue, R.R., "Internet site evaluations: The influence of behavioral experience, existing images, and selected website characteristics”, Journal of Travel \& Tourism Marketing, 11 (2/3), 21-38, 2012.

[21] Rowley, J., "Remodeling marketing communications in an internet environment”, Internet Research, 11 (3), 203-212, 2001.

[22] Ruiz-Mafé, C., Sanz-Blas, S. and Aldás-Manzano, J., "Drivers and barriers to online airline ticket purchasing”, Journal of Air Transport Management, 15 (6), 294-298, 2009.

[23] Sam, M.F.M. and Tahir, M.N.H., "Website quality and consumer online purchase intention of air ticket”, International Journal of Basic \& Applied Sciences, 9 (10), 20-25, 2009.

[24] Shchiglik, C. and Barnes, S.J., "Evaluating website quality in the airline industry”, Journal of Computer Information Systems, 44 (3), 17-25, 2004.

[25] Tsai, W.H., Chou, W.C. and Leu, J.D., “An effectiveness evaluation model for the web-based marketing of the airline industry”, Expert Systems with Applications, 38 (12), 1549915516, 2011.

[26] Xie, Z.C. and Barnes, S.J., "Web site quality in the UK airline industry: A longitudinal examination”, Journal of Computer Information Systems, 49 (2), 50-57, 2008.

[27] Yoon, M.G., Yoon, D.Y. and Yang, T.W., "Impact of e-business on air travel markets: Distribution of airline tickets in Korea", Journal of Air Transport Management, 12 (5), 253-260, 2006.

[28] http://www.internetworldstats.com/stats.htm, [Accessed, Jan. 7, 2015]. 
Appendix 1. Original Version of the Scoring System

\begin{tabular}{|l|}
\hline FUNCTIONS \\
\hline Information Provision \\
Additive index -1 point assigned for each item present $(0-15)$ \\
\hline Organisational history \\
\hline Structure \\
\hline Values/ideology \\
\hline Policies \\
\hline Manifesto \\
\hline Media releases \\
\hline Speeches \\
\hline People/Who's Who \\
\hline Leader focus \\
\hline Candidate profiles \\
\hline Electoral information 1 (statistics, information on past performance) \\
\hline Electoral information 2 (postal voting info/voting registration) \\
\hline Event calendar (prospective or retrospective) \\
\hline Frequently asked questions \\
\hline Article archive or library \\
\hline
\end{tabular}

\section{Resource Generation}

Cumulative index (0-12) Three ordinal indices:

(i) Donation index 0 - 4

(ii) Merchandise index $0-4$

(iii) Membership index. $0-4$

For each index (1) reference made and postal address listed (2) download and post form (3)

Mixed email enquiry and/or download form (4) fully online transaction

\section{Networking}

Internal

Candidates

Local parties

Other internal groups

External

Partisan links (associated orgs e.g. TUs sister parties etc.)

Reference links are those to neutral or news/educational sites such as news, broadcasters, newspapers, Parliamentary/government sites, national libraries etc.

Commercial links are those promoting business services such as book sellers etc.

Opponants

\section{Participation}

Additive index $(0-10)$

Openness $(0-4)$

E-mail leader

E-mail other politicians/candidates

E-mail hq general

E-mail named officials/staff

Feedback (0-3)

General feedback on the website etc.

Feedback issues/policy general

Solicited email feedback on specific issue

Interactive debate/comment (0-4)

Discussion fora

Campaign diary/blog without comment facility

Blog with comments

Online q\&a

Interaction with site (0-2)

Opinion polls

Games

\section{Campaigning :}

Additive index - 1 point assigned for each item present $(0-8)$

Negative campaigning (banner, pop-up ad etc. on home page)

Targeting ex-pat voters

Targeting marginal constituency/swing voter (explicit effort)

Join an email update list

Become online campaigner

Send a link/e-postcard

Download literature

Download screensavers/ banners

\section{DELIVERY}

Multimedia/Glitz Factor

Additive index 1 point for each item present (0-5)

Sound 


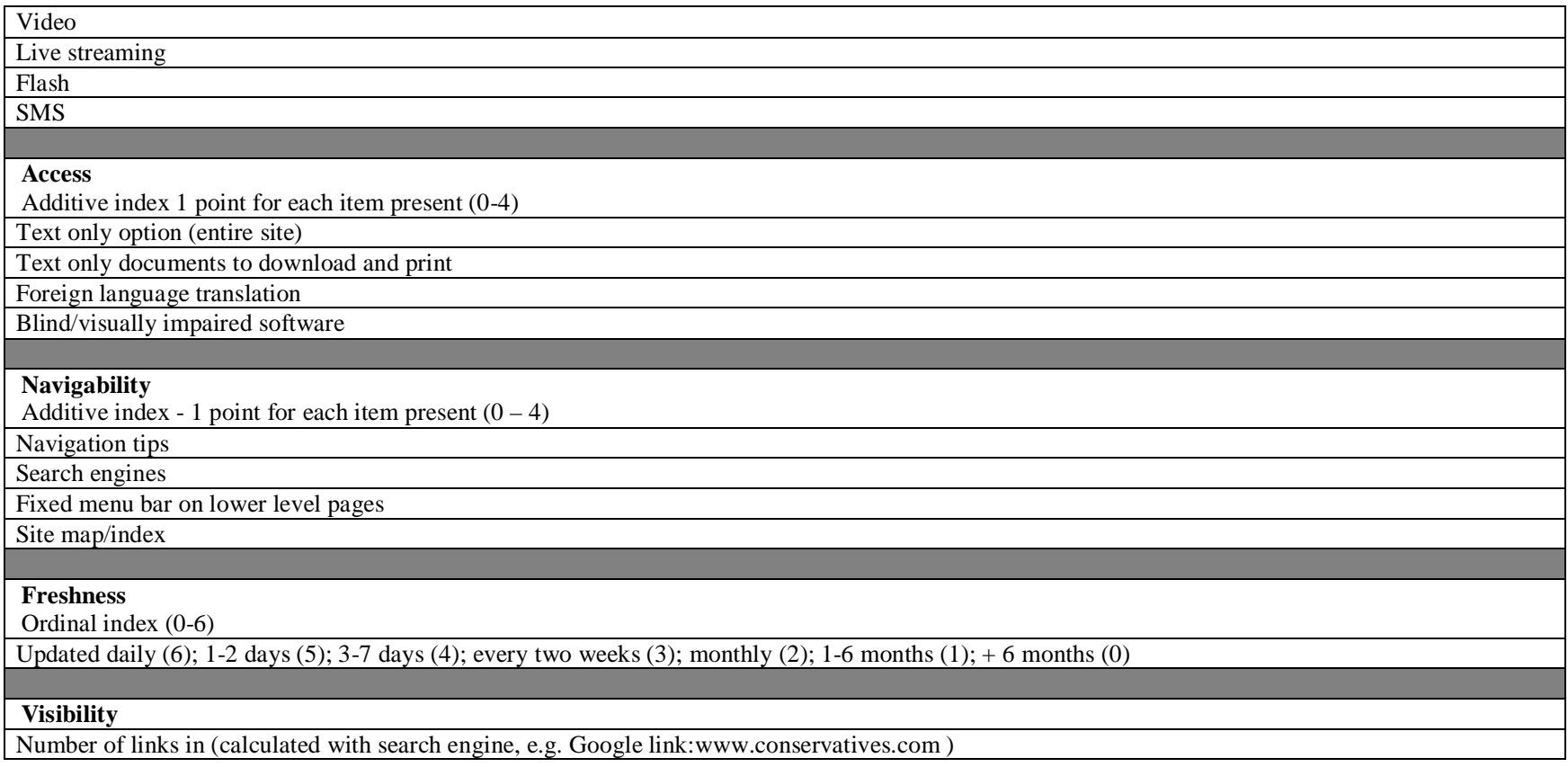

Appendix 2. Modified Version of the Scoring System and Analysis of the Websites FUNCTIONS

\begin{tabular}{|c|c|c|c|c|c|c|c|c|c|c|c|c|c|c|}
\hline \multicolumn{15}{|c|}{ FUNCTIONS } \\
\hline \multicolumn{15}{|c|}{$\begin{array}{l}\text { A. INFORMATION PROVISION } \\
\text { All items are } 1 \text { point. Total index }(0-21)\end{array}$} \\
\hline & \multicolumn{2}{|c|}{ ANADOLU } & \multicolumn{2}{|c|}{ ATLAS } & \multicolumn{2}{|c|}{ BORA } & \multicolumn{2}{|c|}{ ONUR } & \multicolumn{2}{|c|}{ PEGASUS } & \multicolumn{2}{|c|}{ SUNEXPRESS } & \multicolumn{2}{|c|}{ THY } \\
\hline & 2012 & 2014 & 2012 & 2014 & 2012 & 2014 & 2012 & 2014 & 2012 & 2014 & 2012 & 2014 & 2012 & 2014 \\
\hline History & 1 & 1 & 1 & 1 & 1 & 1 & 1 & 1 & 1 & 1 & 1 & 1 & 1 & 1 \\
\hline $\begin{array}{l}\text { Organizationa } \\
\text { l Structure }\end{array}$ & 0 & 0 & 1 & 1 & 1 & 1 & 1 & 1 & 1 & 1 & 1 & 0 & 1 & 1 \\
\hline $\begin{array}{l}\text { Vision/Missio } \\
\mathrm{n}\end{array}$ & 0 & 0 & 1 & 1 & 1 & 1 & 1 & 1 & 1 & 1 & 1 & 0 & 1 & 1 \\
\hline $\begin{array}{l}\text { Annual } \\
\text { Reports }\end{array}$ & 0 & 0 & 0 & 0 & 0 & 0 & 1 & 1 & 0 & 0 & 0 & 0 & 1 & 1 \\
\hline Quality Policy & 0 & 0 & 1 & 1 & 0 & 0 & 1 & 1 & 1 & 1 & 1 & 1 & 1 & 1 \\
\hline Pressroom & 1 & \begin{tabular}{|l|}
1 \\
\end{tabular} & 0 & 0 & 0 & 0 & 1 & \begin{tabular}{|l|}
1 \\
\end{tabular} & 1 & 1 & $\begin{array}{l}1 \\
\end{array}$ & 1 & \begin{tabular}{|l|}
1 \\
\end{tabular} & 1 \\
\hline Who is who & 0 & 0 & 0 & 1 & 1 & 1 & 0 & 0 & 1 & 1 & 0 & 0 & 1 & 1 \\
\hline CEO-Leader & 0 & 0 & 0 & 1 & 0 & 0 & 0 & 0 & 1 & 1 & 0 & 0 & 1 & 1 \\
\hline FAQ & 1 & 1 & 1 & 1 & 1 & 1 & 1 & 1 & 1 & 1 & 1 & 1 & 1 & 1 \\
\hline $\begin{array}{l}\text { Privacy } \\
\text { Policy (for } \\
\text { customers) }\end{array}$ & 1 & 1 & 1 & 1 & 1 & 1 & 0 & 0 & 1 & 1 & 1 & 1 & 1 & 1 \\
\hline Archive & 0 & 0 & 1 & 1 & 0 & 0 & 0 & 0 & 1 & 1 & 0 & 0 & 1 & 1 \\
\hline Car Rental & 1 & 1 & 0 & 1 & 0 & 0 & 1 & 1 & 1 & 1 & 1 & 1 & 1 & 1 \\
\hline $\begin{array}{l}\text { Hotel } \\
\text { Reservation }\end{array}$ & 0 & 0 & 1 & 1 & 0 & 0 & 1 & 1 & 1 & 1 & 1 & 1 & 1 & 1 \\
\hline $\begin{array}{l}\text { Country/City } \\
\text { Guide }\end{array}$ & 1 & 1 & 0 & 0 & 0 & 0 & 0 & 0 & 1 & 1 & 1 & 1 & 1 & 1 \\
\hline $\begin{array}{l}\text { Corporate } \\
\text { Publications }\end{array}$ & 1 & 1 & 1 & 1 & 0 & 0 & 1 & 1 & 1 & 1 & 0 & 1 & 1 & 1 \\
\hline Fleet & 1 & 1 & 1 & 1 & 1 & 1 & 1 & 1 & 1 & 1 & 1 & 1 & 1 & 1 \\
\hline $\begin{array}{l}\text { Security } \\
\text { Policy }\end{array}$ & 1 & 1 & 1 & 1 & 0 & 0 & 0 & 1 & 1 & 1 & 1 & 1 & 1 & 1 \\
\hline Cargo & 1 & 1 & 0 & 0 & 0 & 0 & 1 & 1 & 1 & 1 & 1 & 1 & 1 & 1 \\
\hline $\begin{array}{l}\text { Human } \\
\text { Resources }\end{array}$ & 0 & 0 & 1 & 1 & 0 & 1 & 1 & 1 & 1 & 1 & 1 & 1 & 1 & 1 \\
\hline $\begin{array}{l}\text { Customer } \\
\text { Relations }\end{array}$ & 1 & 1 & 1 & 1 & 0 & 1 & 1 & 1 & 1 & 1 & 1 & 1 & 1 & 1 \\
\hline Left Luggage & 1 & 1 & 0 & 0 & 0 & 0 & 1 & 1 & 1 & 1 & 1 & 1 & 1 & 1 \\
\hline Total & \begin{tabular}{|l|}
12 \\
\end{tabular} & 12 & 13 & 16 & 7 & 9 & \begin{tabular}{|l|}
15 \\
\end{tabular} & \begin{tabular}{|l|}
16 \\
\end{tabular} & 20 & 20 & 16 & 15 & 21 & 21 \\
\hline \multicolumn{13}{|c|}{ B. NETWORKING } & & \\
\hline & \multicolumn{2}{|c|}{ ANADOLU } & \multicolumn{2}{|c|}{ ATLAS } & \multicolumn{2}{|c|}{ BORA } & \multicolumn{2}{|c|}{ ONUR } & \multicolumn{2}{|c|}{ PEGASUS } & \multicolumn{2}{|c|}{\begin{tabular}{|l} 
SUNEXPRESS \\
\end{tabular}} & \multicolumn{2}{|c|}{ THY } \\
\hline & 2012 & 2014 & 2012 & 2014 & 2012 & 2014 & 2012 & 2014 & 2012 & 2014 & 2012 & 2014 & 2012 & 2014 \\
\hline $\begin{array}{l}\text { E-mails of } \\
\text { Managers }\end{array}$ & 0 & 0 & 0 & 0 & 0 & 0 & 0 & 0 & 0 & 0 & 0 & 0 & 0 & 0 \\
\hline $\begin{array}{l}\text { E-mails of } \\
\text { Agencies }\end{array}$ & 5 & 5 & 5 & 5 & 0 & 5 & 0 & 0 & 3 & 3 & 1 & 1 & 5 & 5 \\
\hline $\begin{array}{l}\text { Head Office } \\
\text { Contact } \\
\text { Information }\end{array}$ & 5 & 5 & 2 & 2 & 1 & 1 & 3 & 3 & 1 & 1 & 1 & 1 & 5 & 5 \\
\hline
\end{tabular}




\begin{tabular}{|c|c|c|c|c|c|c|c|c|c|c|c|c|c|c|}
\hline $\begin{array}{l}\text { Reference } \\
\text { Links }\end{array}$ & 1 & 1 & 5 & 5 & 1 & 1 & 5 & 5 & 5 & 5 & 5 & 5 & 5 & 5 \\
\hline Total & 11 & 11 & 12 & 12 & 2 & 7 & 8 & 8 & 9 & 9 & 7 & 7 & 15 & 15 \\
\hline \multicolumn{15}{|c|}{$\begin{array}{l}\text { C. PARTICIPATION } \\
\text { All items are } 1 \text { point. Total index }(0-4)\end{array}$} \\
\hline & \multicolumn{2}{|c|}{ ANADOLU } & \multicolumn{2}{|c|}{ ATLAS } & \multicolumn{2}{|c|}{ BORA } & \multicolumn{2}{|c|}{ ONUR } & \multicolumn{2}{|c|}{ PEGASUS } & \multicolumn{2}{|c|}{ SUNEXPRESS } & \multicolumn{2}{|c|}{ THY } \\
\hline & 2012 & 2014 & 2012 & 2014 & 2012 & 2014 & 2012 & 2014 & 2012 & 2014 & 2012 & 2014 & 2012 & 2014 \\
\hline Forum & 0 & 0 & 0 & 0 & 0 & 0 & 0 & 0 & 0 & 0 & 0 & 1 & 0 & 0 \\
\hline Membership & 1 & 1 & 0 & 0 & 1 & 1 & 0 & 0 & 1 & 1 & 1 & 1 & 1 & 1 \\
\hline $\begin{array}{l}\text { Customer } \\
\text { Opinions and } \\
\text { Suggesstions }\end{array}$ & 0 & 0 & 0 & 0 & 0 & 1 & 0 & 0 & 0 & 0 & 0 & 0 & 0 & 0 \\
\hline Games & 0 & 0 & 0 & 0 & 0 & 0 & 0 & 0 & 0 & 0 & 0 & 0 & 0 & 0 \\
\hline Total & 1 & 1 & $\mathbf{0}$ & $\mathbf{0}$ & 1 & 2 & 0 & 0 & 1 & 1 & 1 & 2 & 1 & 1 \\
\hline \multicolumn{15}{|c|}{$\begin{array}{l}\text { D. CAMPAIGNING } \\
\text { All items are } 1 \text { point. Total index (0-3) }\end{array}$} \\
\hline & \multicolumn{2}{|c|}{ ANADOLU } & \multicolumn{2}{|c|}{ ATLAS } & \multicolumn{2}{|c|}{ BORA } & \multicolumn{2}{|c|}{ ONUR } & \multicolumn{2}{|c|}{ PEGASUS } & \multicolumn{2}{|c|}{\begin{tabular}{|l|} 
SUNEXPRESS \\
\end{tabular}} & \multicolumn{2}{|c|}{ THY } \\
\hline & 2012 & 2014 & 2012 & 2014 & 2012 & 2014 & 2012 & 2014 & 2012 & 2014 & 2012 & 2014 & 2012 & 2014 \\
\hline $\begin{array}{l}\text { Attending } \\
\text { Online } \\
\text { Campaign }\end{array}$ & 1 & 1 & 0 & 0 & 0 & 0 & 0 & 0 & 1 & 1 & 1 & 1 & 1 & 1 \\
\hline $\begin{array}{l}\text { Download } \\
\text { Logo }\end{array}$ & 1 & 1 & 0 & 0 & 0 & 0 & 1 & 1 & 1 & 1 & 0 & 0 & 1 & 1 \\
\hline $\begin{array}{l}\text { Download } \\
\text { Brochure and } \\
\text { Campaign } \\
\text { Information }\end{array}$ & 0 & 0 & 0 & 0 & 0 & 0 & 1 & 1 & 1 & 1 & 0 & 0 & 1 & 1 \\
\hline Total & 2 & 2 & $\mathbf{0}$ & $\mathbf{0}$ & $\mathbf{0}$ & $\mathbf{0}$ & 2 & 2 & 3 & 3 & 1 & 1 & 3 & 3 \\
\hline & & & & & $\begin{array}{r}\mathbf{E} \\
\text { All it } \\
\end{array}$ & $\begin{array}{l}\text { ONLIN } \\
\text { ems are } 1 \\
\end{array}$ & $\begin{array}{l}\text { APPLI } \\
\text { point. Tc }\end{array}$ & $\begin{array}{l}\text { CATIOI } \\
\text { tal index }\end{array}$ & $\begin{array}{l}\mathbf{S} \\
(0-5) \\
\end{array}$ & & & & & \\
\hline & ANA & DOLU & & LAS & & RA & & UR & PE & SASUS & SUNE & PRESS & & CHY \\
\hline & 2012 & 2014 & 2012 & 2014 & 2012 & 2014 & 2012 & \begin{tabular}{|l|}
2014 \\
\end{tabular} & 2012 & 2014 & 2012 & 2014 & 2012 & 2014 \\
\hline $\begin{array}{l}\text { Online } \\
\text { Reservation }\end{array}$ & 1 & 1 & 1 & 1 & 1 & 1 & 1 & 1 & 1 & 1 & 1 & 1 & 1 & 1 \\
\hline $\begin{array}{l}\text { Online Ticket } \\
\text { Sale }\end{array}$ & 1 & 1 & 1 & 1 & 1 & 1 & 1 & 1 & 1 & 1 & 1 & 1 & 1 & 1 \\
\hline $\begin{array}{l}\text { Online } \\
\text { Check-in }\end{array}$ & 1 & 1 & 1 & 1 & 1 & 1 & 1 & 1 & 1 & 1 & 1 & 1 & 1 & 1 \\
\hline $\begin{array}{l}\text { Online } \\
\text { Baggage } \\
\text { Tracking }\end{array}$ & 1 & 1 & 0 & 0 & 0 & 0 & 0 & 0 & 1 & 1 & 0 & 0 & 1 & 1 \\
\hline $\begin{array}{l}\text { Online Cargo } \\
\text { Tracking }\end{array}$ & 1 & 1 & 0 & 0 & 0 & 0 & 0 & 0 & 0 & 1 & 0 & 0 & 1 & 1 \\
\hline Total & 5 & 5 & 3 & 3 & 3 & 3 & 3 & 3 & 4 & 5 & 3 & 3 & 5 & 5 \\
\hline & & & & & $\begin{array}{r}\mathbf{F} \\
\text { All it }\end{array}$ & $\begin{array}{l}\text { MOBIL } \\
\text { ems are } 1\end{array}$ & $\begin{array}{l}\text { E APPLI } \\
\text { point. Tc }\end{array}$ & $\begin{array}{l}\text { CATIOI } \\
\text { tal index }\end{array}$ & $\begin{array}{l} \\
(0-6) \\
\end{array}$ & & & & & \\
\hline & ANA & $\overline{D O L U}$ & & LAS & & RA & & UR & PE & SASUS & \begin{tabular}{|l|} 
SUNE \\
\end{tabular} & PRESS & & CHY \\
\hline & 2012 & 2014 & 2012 & 2014 & 2012 & 2014 & 2012 & \begin{tabular}{|l|}
2014 \\
\end{tabular} & 2012 & 2014 & 2012 & 2014 & 2012 & 2014 \\
\hline $\begin{array}{l}\text { Iphone } \\
\text { Application }\end{array}$ & 0 & 1 & 1 & 1 & 0 & 0 & 0 & 1 & 0 & 1 & 0 & 0 & 1 & 1 \\
\hline $\begin{array}{l}\text { Blackberry } \\
\text { Application }\end{array}$ & 0 & 0 & 1 & 0 & 0 & 0 & 0 & 0 & 0 & 0 & 0 & 0 & 1 & 1 \\
\hline $\begin{array}{l}\text { Java } \\
\text { Application }\end{array}$ & 0 & 0 & 0 & 0 & 0 & 0 & 0 & 0 & 0 & 0 & 0 & 0 & 1 & 1 \\
\hline $\begin{array}{l}\text { Wap } \\
\text { Application }\end{array}$ & 0 & 0 & 0 & 0 & 0 & 0 & 0 & 0 & 0 & 0 & 0 & 0 & 1 & 1 \\
\hline Android & 0 & 1 & 1 & 1 & 0 & 0 & 0 & 1 & 0 & 1 & 0 & 0 & 1 & 1 \\
\hline Tablet & 0 & 0 & 1 & 1 & 0 & 0 & 0 & 1 & 0 & 1 & 0 & 0 & 0 & 1 \\
\hline Total & 0 & 2 & 1 & 3 & 0 & 0 & 0 & 3 & 0 & 3 & 0 & $\mathbf{0}$ & 0 & 6 \\
\hline & & & & & $\begin{array}{r}\text { G. SO } \\
\text { All it }\end{array}$ & $\begin{array}{l}\text { CIAL } \mathbf{M} \\
\text { ems are } 1\end{array}$ & $\begin{array}{l}\text { EDIA AI } \\
\text { point. Tc }\end{array}$ & $\begin{array}{l}\text { PLICAT } \\
\text { tal index }\end{array}$ & $\begin{array}{l}\text { IONS } \\
(0-6) \\
\end{array}$ & & & & & \\
\hline & ANA & $\overline{\mathrm{DOLU}}$ & & LAS & & RA & & UR & PE & SASUS & \begin{tabular}{|l|} 
SUNE \\
\end{tabular} & PRESS & & CHY \\
\hline & 2012 & 2014 & 2012 & 2014 & 2012 & 2014 & 2012 & 2014 & 2012 & 2014 & 2012 & 2014 & 2012 & 2014 \\
\hline RSS & 1 & 1 & 0 & 0 & 0 & 0 & 0 & 0 & 1 & 0 & 0 & 0 & 1 & 1 \\
\hline Facebook & 1 & 1 & 1 & 1 & 1 & 1 & 1 & 1 & 1 & 1 & 0 & 1 & 1 & 1 \\
\hline Twitter & 1 & 1 & 1 & 1 & 1 & 1 & 1 & 1 & 1 & 1 & 0 & 1 & 1 & 1 \\
\hline Google + & 0 & 0 & 1 & 1 & 0 & 0 & 1 & 1 & 1 & 1 & 0 & 1 & 1 & 1 \\
\hline You tube & 0 & 0 & 0 & 0 & 0 & 1 & 0 & 0 & 1 & 1 & 0 & 1 & 1 & 1 \\
\hline Flickr & 0 & 0 & 0 & 0 & 0 & 0 & 0 & 0 & 0 & 0 & 0 & 0 & 1 & 1 \\
\hline Total & 3 & 3 & 3 & 3 & 2 & 3 & 3 & 3 & 5 & 4 & 0 & 4 & 6 & 6 \\
\hline & & & & & & & ELIVER & & & & & & & \\
\hline & & & & & All it & $\begin{array}{r}\text { A.GL } \\
\text { ms are } 1\end{array}$ & $\begin{array}{l}\text { ITZ FAC } \\
\text { point. Ts }\end{array}$ & $\begin{array}{l}\text { TOR } \\
\text { tal inde }\end{array}$ & $(0-6)$ & & & & & \\
\hline Design Index A & ll items & re 1 point & Total in & lex $(0-3)$ & & & & & & & & & & \\
\hline & ANA & DOLU & & LAS & & RA & & UR & PE & SASUS & SUNE & PRESS & & CHY \\
\hline & 2012 & 2014 & 2012 & 2014 & 2012 & 2014 & 2012 & 2014 & 2012 & 2014 & 2012 & 2014 & 2012 & 2014 \\
\hline Graphics: & 1 & 1 & 1 & 1 & 1 & 1 & 1 & 1 & 1 & 1 & 1 & 1 & 1 & 1 \\
\hline
\end{tabular}




\begin{tabular}{|c|c|c|c|c|c|c|c|c|c|c|c|c|c|c|}
\hline Frames: & 1 & 1 & 1 & 1 & 1 & 1 & 1 & 1 & 1 & 1 & 1 & 1 & 1 & 1 \\
\hline $\begin{array}{l}\text { Moving/imag } \\
\text { es }\end{array}$ & 1 & 1 & 1 & 1 & 1 & 1 & 1 & 1 & 1 & 1 & 0 & 0 & 1 & 1 \\
\hline Total & 3 & 3 & 3 & 3 & 3 & 3 & 3 & 3 & 3 & 3 & 2 & 2 & 3 & 3 \\
\hline \multicolumn{15}{|c|}{ Multimedia Index All items are 1 point. Total index $(0-3)$} \\
\hline & \multicolumn{2}{|c|}{ ANADOLU } & \multicolumn{2}{|c|}{ ATLAS } & \multicolumn{2}{|c|}{ BORA } & \multicolumn{2}{|c|}{ ONUR } & \multicolumn{2}{|c|}{ PEGASUS } & \multicolumn{2}{|c|}{ SUNEXPRESS } & \multicolumn{2}{|c|}{ THY } \\
\hline & 2012 & 2014 & 2012 & 2014 & 2012 & 2014 & 2012 & 2014 & 2012 & 2014 & 2012 & 2014 & 2012 & 2014 \\
\hline Sound & 1 & 1 & 0 & 0 & 0 & 0 & 1 & 1 & 0 & 0 & 0 & 0 & 1 & 1 \\
\hline Video & 1 & \begin{tabular}{|l|l}
1 \\
\end{tabular} & 0 & 0 & 0 & 0 & 1 & 1 & 0 & 0 & 0 & 0 & 1 & 1 \\
\hline $\begin{array}{l}\text { Live } \\
\text { streaming }\end{array}$ & 1 & 1 & 1 & 1 & 1 & 1 & 0 & 1 & 0 & 0 & 0 & 0 & 1 & 1 \\
\hline Total & 3 & 3 & 1 & 1 & 1 & 1 & 2 & 3 & $\mathbf{0}$ & 0 & 0 & $\mathbf{0}$ & 3 & 3 \\
\hline $\begin{array}{l}\text { Design- } \\
\text { Multimedia } \\
\text { Total }\end{array}$ & 6 & 6 & 4 & 4 & 4 & 4 & 5 & 6 & 3 & 3 & 2 & 2 & 6 & 6 \\
\hline \multicolumn{15}{|c|}{$\begin{array}{c}\text { B.ACCESS } \\
\text { All items are } 1 \text { point. Total index }(0-7) \\
\end{array}$} \\
\hline & \multicolumn{2}{|c|}{ ANADOLU } & \multicolumn{2}{|c|}{ ATLAS } & \multicolumn{2}{|c|}{ BORA } & \multicolumn{2}{|c|}{ ONUR } & \multicolumn{2}{|c|}{ PEGASUS } & \multicolumn{2}{|c|}{\begin{tabular}{|l|l|} 
SUNEXPRESS \\
\end{tabular}} & \multicolumn{2}{|c|}{ THY } \\
\hline & 2012 & 2014 & 2012 & 2014 & 2012 & 2014 & 2012 & 2014 & 2012 & 2014 & 2012 & 2014 & 2012 & 2014 \\
\hline $\begin{array}{l}\text { No frames } \\
\text { option }\end{array}$ & 0 & 0 & 0 & 0 & 0 & 0 & 0 & 0 & 0 & 0 & 0 & 0 & 0 & 0 \\
\hline $\begin{array}{l}\text { Text only } \\
\text { option (entire } \\
\text { site) }\end{array}$ & 1 & 1 & 1 & 1 & 1 & 1 & 1 & 1 & 1 & 1 & 1 & 1 & 1 & 1 \\
\hline $\begin{array}{l}\text { Text only } \\
\text { documents to } \\
\text { download and } \\
\text { print }\end{array}$ & 0 & 0 & 0 & 0 & 0 & 0 & 1 & 1 & 0 & 1 & 0 & 0 & 1 & 1 \\
\hline $\begin{array}{l}\text { WAP / PDA } \\
\text { "wireless" } \\
\text { enabled }\end{array}$ & 0 & 0 & 1 & 1 & 1 & 1 & 1 & 1 & 1 & 1 & 0 & 0 & 0 & 0 \\
\hline $\begin{array}{l}\text { Foreign } \\
\text { language } \\
\text { translation }\end{array}$ & 1 & 1 & $1(2)$ & 1 & $1(2)$ & 1 & 1 & 1 & $1(8)$ & 1 & $1(2)$ & 1 & $1(22)$ & 1 \\
\hline $\begin{array}{l}\text { Blind/visually } \\
\text { impaired } \\
\text { software }\end{array}$ & 0 & 0 & 0 & 0 & 0 & 0 & 0 & 0 & 0 & 0 & 0 & 0 & 0 & 0 \\
\hline $\begin{array}{l}\text { In practice: } \\
\text { Size of home } \\
\text { page in KB }\end{array}$ & $\begin{array}{l}1.15 \mathrm{M} \\
\mathrm{B}\end{array}$ & $1.25 \mathrm{MB}$ & $\begin{array}{l}465 \mathrm{~K} \\
\mathrm{~B}\end{array}$ & $\begin{array}{l}1.84 \mathrm{M} \\
\mathrm{B}\end{array}$ & $\begin{array}{l}639 \mathrm{~K} \\
\mathrm{~B}\end{array}$ & $\begin{array}{l}3.03 \mathrm{M} \\
\mathrm{B}\end{array}$ & $\begin{array}{l}1.82 \mathrm{M} \\
\mathrm{B}\end{array}$ & $\begin{array}{l}2.01 \mathrm{M} \\
\mathrm{B}\end{array}$ & $\begin{array}{l}1.33 \mathrm{M} \\
\mathrm{B}\end{array}$ & $1.41 \mathrm{MB}$ & $\begin{array}{l}5.98 \mathrm{M} \\
\mathrm{B}\end{array}$ & $\begin{array}{l}2.19 \mathrm{M} \\
\mathrm{B}\end{array}$ & $\begin{array}{l}1.21 \mathrm{M} \\
\mathrm{B}\end{array}$ & $1.21 \mathrm{MB}$ \\
\hline Total & 2 & 2 & 3 & 3 & 3 & 3 & 4 & 4 & 3 & 4 & 2 & 2 & 3 & 3 \\
\hline \multicolumn{15}{|c|}{$\begin{array}{c}\text { C.NAVIGABILITY } \\
\text { All items are } 1 \text { point. Total index (0-4) }\end{array}$} \\
\hline & \multicolumn{2}{|c|}{ ANADOLU } & \multicolumn{2}{|c|}{ ATLAS } & \multicolumn{2}{|c|}{ BORA } & \multicolumn{2}{|c|}{ ONUR } & \multicolumn{2}{|c|}{ PEGASUS } & \multicolumn{2}{|c|}{\begin{tabular}{|l} 
SUNEXPRESS \\
\end{tabular}} & & HY \\
\hline & 2012 & 2014 & 2012 & 2014 & 2012 & 2014 & 2012 & 2014 & 2012 & 2014 & 2012 & 2014 & 2012 & 2014 \\
\hline $\begin{array}{l}\text { Search } \\
\text { engines }\end{array}$ & 1 & 1 & 0 & 0 & 0 & 1 & 0 & 0 & 0 & 0 & 1 & 0 & 1 & 1 \\
\hline $\begin{array}{l}\text { Home page } \\
\text { icon on lower } \\
\text { level pages }\end{array}$ & 0 & 0 & 0 & 0 & 0 & 0 & 0 & 0 & 0 & 0 & 0 & 0 & 0 & 0 \\
\hline $\begin{array}{l}\text { Fixed menu } \\
\text { bar on lower } \\
\text { level pages }\end{array}$ & 1 & 1 & 1 & 1 & 1 & 1 & 1 & 1 & 0 & 0 & 0 & 0 & 1 & 1 \\
\hline Site map/index & \begin{tabular}{|l|l}
1 \\
\end{tabular} & 1 & 0 & 0 & 0 & 1 & 0 & 0 & 1 & 1 & 1 & 1 & 1 & 0 \\
\hline Total & 3 & 3 & 1 & 1 & 1 & 3 & 1 & 1 & 1 & 1 & 2 & 1 & 3 & 2 \\
\hline & Updat & d: Ever & $\operatorname{ly}(6)$ & 2 days & 3-7 & $\begin{array}{r}\text { D.F } \\
\text { Ordi } \\
\text { vs (4); ev }\end{array}$ & $\begin{array}{l}\text { RESHN } \\
\text { hal index } \\
\text { ery two }\end{array}$ & $\begin{array}{l}\text { SS } \\
(0-6) \\
\text { eeks (3); }\end{array}$ & monthly & 2): $1-6 \mathrm{mc}$ & ths (1); & months & & \\
\hline & ANA & DOLU & & LAS & & RA & & UR & PE & SASUS & SUNE & PRESS & & $\mathrm{HY}$ \\
\hline & 2012 & 2014 & 2012 & 2014 & 2012 & 2014 & 2012 & 2014 & 2012 & 2014 & 2012 & 2014 & 2012 & 2014 \\
\hline & 1 & 6 & 2 & 2 & 2 & 4 & 2 & 0 & 4 & 7 & 3 & 5 & 4 & 5 \\
\hline & & & & & & $\begin{array}{r}\text { E. } \\
\text { Link nuı }\end{array}$ & mbers (G & OOGLE) & & & & & & \\
\hline & ANA & $\overline{\text { DOLU }}$ & & LAS & & RA & & UR & PE & GASUS & SUNE & PRESS & & HY \\
\hline & 2012 & 2014 & 2012 & 2014 & 2012 & 2014 & 2012 & 2014 & 2012 & 2014 & 2012 & 2014 & 2012 & 2014 \\
\hline & 31.100 & $\begin{array}{l}1.440 .00 \\
0\end{array}$ & 46.40 & $\begin{array}{l}797.00 \\
0\end{array}$ & $\begin{array}{ll}16.80 \\
0\end{array}$ & $\begin{array}{l}450.00 \\
0\end{array}$ & 91.100 & $\begin{array}{l}201.00 \\
0\end{array}$ & $\begin{array}{l}206.00 \\
0\end{array}$ & $\begin{array}{l}21.800 .00 \\
0\end{array}$ & $\begin{array}{l}418.00 \\
0\end{array}$ & $\begin{array}{l}839.00 \\
0\end{array}$ & $\begin{array}{l}698.00 \\
0\end{array}$ & $\begin{array}{l}26.400 .00 \\
0\end{array}$ \\
\hline
\end{tabular}

